\title{
Gold grains in laterite weathering profiles of Nilambur, South India and a model for the genesis of supergene gold deposits
}

\author{
M. SANTOSH ${ }^{* * *}$, P.K. OMANA** and MASARU YoShIDA* \\ - Department of Geosciences, Osaka City University, Osaka 558 \\ * Centre for Earth Science Studies, Trivandnem 695 0.31, India
}

\begin{abstract}
Occurrence of dust, coarse grains and even large nuggets of gold in laterite weathering profiles has emerged as a recent challenge to metallogeny. Supergene gold concentrations, as in Nilambur, South India, show morphological and textural characteristics indicative of chemical dissolution, migration and reprecipitation by low temperature solutions in weathering environments, The gold grains from the upper zones have neat-spherical shapes with numerous etch pits, while those from the lower zones are of more irregular in shape and are less corroded. Textural features like filamental, dendritic or tuft-like patterns and the petaloids or coatings of "painted gold" over the primary grains indicate that they are the products of incipient growth of secondary gold. Based on their nature of occurrence and grain morphology, we develop a model involving the oxidation of pyrite to form an acidic profile which dissolved gold and transported it as chloride complexes from the primary veins. In the high Eh and neutral to alkaline environment of the oxidized zone, these complexes got dissociated and pure metal was precipitated. Chemical reprecipitation has often led to an increase in the "fineness" (purity) of gold formed in supergene environments.
\end{abstract}

\section{Introduction}

One of the surprising challenges in metal. logeny in the recent years is the occurrence of gold at economic levels in laterites which are tropical weathering products (Wilson, 1984). Although the physico-chemical conditions governing primary gold precipitation from pneumatolytic and hydrothermal solutions at relatively high pressure-temperature conditions have been studied for many years, the charac. teristics of supergene gold have received less attention till the recent experimental investigations which identify the role of oxide, sulfide and chloride complexes, Eh-pH variations and temperature fluctuations as constraining factors for the mobility of gold in low temperature environments related to weathering processes (Boyle, 1979; Mann, 1983, 1984). Although the mere occurrence of visible gold particles in laterites could be ascribed to hypogene gold arising from the weathering of primary aurifeous veins in the vicinity, a closer examina. tion reveals that such occurrences are not merely dictated by a simple hypogene model, but involve complex chemical reactions leading to reconcentration of primary gold into grains of increased size and "fineness" (eg: Wilson, 1984 ; Nair et al., 1987 ; Freyssinet et al., 1989). Gold in weathered profiles has been noted to occur as dust, coarse grains or even large nuggets and is generally free from gangue min. erals, unlike the primary gold. This increase in 'fineness' (quality) and grain size requires that processes of chemical dissolution, migra tion and reprecipitation were instrumental in the genesis of gold in supergene environments. Previous investigations on laterite profiles (eg:

(Manuscript received, June 12, 1990;

accepted for publication, July 12, 1990) 
Nair et al., 1987; Freyssinet et al., 1989) indicated that supergene gold particles have internal and surficial textures typifying secondary concentration at low temperatures. However, the low temperature chemical reactions controlling the formation of supergene gold deposits are not always well constrained.

In this paper, we present the morphological characteristics of gold grains in laterite weathering profiles of the Nilambur area in South India and attempt to develop a model for the physico-chemical environment of dissolution, migration and precipitation of gold in supergene environments.

\section{Types of Gold in Nilambur}

The Nilambur valley lies south of the Wynad Hills tract in Kerala State of South India (Fig. 1). The upper reaches of Chaliyar river and its tributaries draining the slopes of the Nilambur hills have been known to be avenues of avid panning activity by the local people for winning gold from the river bed. Of late, gold is also being recovered from the later. ite matrix of gravels in the old river terraces and from the residual laterites overlying the basement gneisses (Sawarkar, 1980, Nair et al.,

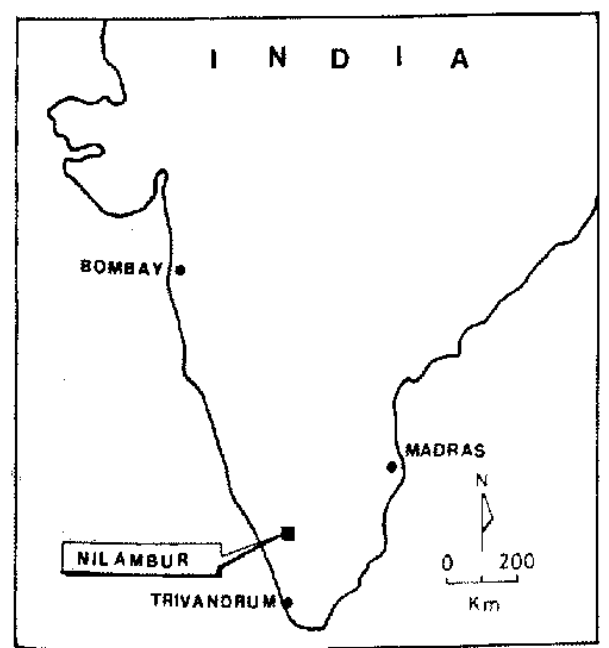

Fig. 1. Map of India showing the location of the laterite-gold occurrence of Nilambur.
1987). The occurrence of gold in Nilambur comes under three categories, namely (1) primary lode gold-sulfide association in vein quartz traversing the Precambrian amphibolites and migmatitic gneisses of the region, (2) supergene gold associated with laterites in weathering profiles and (3) placer gold associated with stream gravels. The lode gold mineralization is mainly restricted to the quartz veins filling shear-fractures. In vein quart $z$, gold occurs as thin films and fine disseminations. Associated gangue minerals are pyrite, chalcopyrite, pyrrhotite and ilmenite. Even where the other gangue minerals are not present, pyrite is invariably noted in association with gold. In some cases, gold is found as inclusions within pyrite. The average grain size of gold in the veins is 200 microns (as measured along the long axis of grains). Fluid inclusion and carbon stable isotopic studies indicate that the primary gold mineralization has resulted from the resurgent precipitation of auriferous carbonic fluids with 'juvenile' isotopic signatures which scavenged the metal from large metamorphic reservoirs with low gold content (Santosh, 1989 and in prep.). Native gold, gold released from sulfides and gold concentrated within laterites have found their way into the eluvium and ultimately into alluvial placers to form the placer deposits of Nilambur.

The laterite cover in Nilambur is broadly of the highly ferruginous and gravelly-type, occurring in the upper most reaches of the mounds and high grounds, as well as on the flanks of the hills. Many vertical sections typically exhibit a sequence of slightly to completely weathered horizons over altered bed-rock (Fig. 2). In many localities, the ferruginous concretions within the lateritic horizon $(\mathrm{H}, \mathrm{W}$. and C.W. in Fig. 2) show pisolitic textures. Nair et al. (1987) have investigated the chemistry of some laterite sections in Nilambur and 

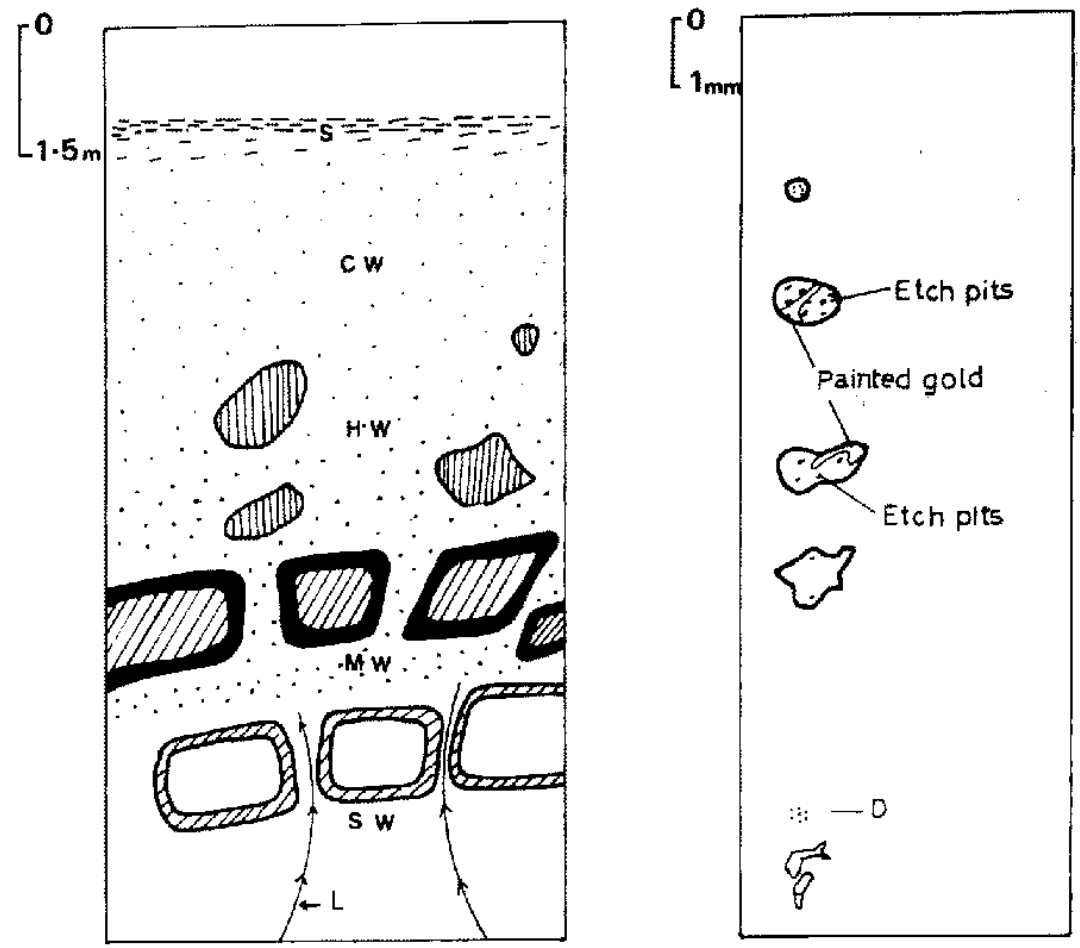

Fig. 2. Characteristic laterite weathering profile of Nilambur showing slighty weathered (SW), moderately weathered (MW), highly weathered (HW), completely weathered (CW) and soil (S) horizons. The arrows with "L" indicate limonite staining. The right-hand figure shows general morphology of gold grains separated from the respective horizons. Etched pits and "painted" textures are indicated. "D" indicates gold cust.

found a negative correlation between the abundance of silica and alumina. Enrichment of iron and increase in the iron: alumina ratios were also noted. Particles of gold occur in most of the zones in the weathering profiles here. Fine gold dust is found within cavities of laterite along with powdery ferric oxides (limonite and hematite). Tiny masses and microcrystals of gold are recovered from the scrapped out powdery material from such cavities. Flakes, flaky aggregates or nuggets, some large enough to be hand-picked are the common forms. In most cases, the characteristic feature is the preferred association of gold with iron-oxide fragments or nodules. They are perched on, attached to or coated around iron-oxides. Sometimes gold particles are also occluded within iron oxides with a rim of gold in the periphery. Grain size measure ments indicate 3 to 4 fold increase in the size of gold in the supergene environment (upto 800 microns) as compared to the primary gold. Average grain size was found to increase within individual laterite profiles from top to bottom.

The placer gold in Nilambur, which is associated with large graveis in the older terraces and also with recent gravels along the bends of river courses, contains contributions from both primary (vein-type) and supergene (laterite-hosted) gold grains, although the major component appears to be from laterites as inferred from the similarity in grain morphology commonly noted between placer gold and laterite gold grains. 


\section{Morphological Characteristics of Laterite- Gold}

For the present study, laterite samples were collected from the various zones of the weathered profiles in the Maruda area of Nilambur, where primary lode gold mineraliza- tion is known to occur in quartz veins traversing Precambrian migmatitic rocks (Nair et al., 1987). Routine techniques of panning and heavy liquid separation were adopted to separate the heavy minerals including gold from the pulverized laterite samples. Gold grains were then carefully hand-picked from the concen-
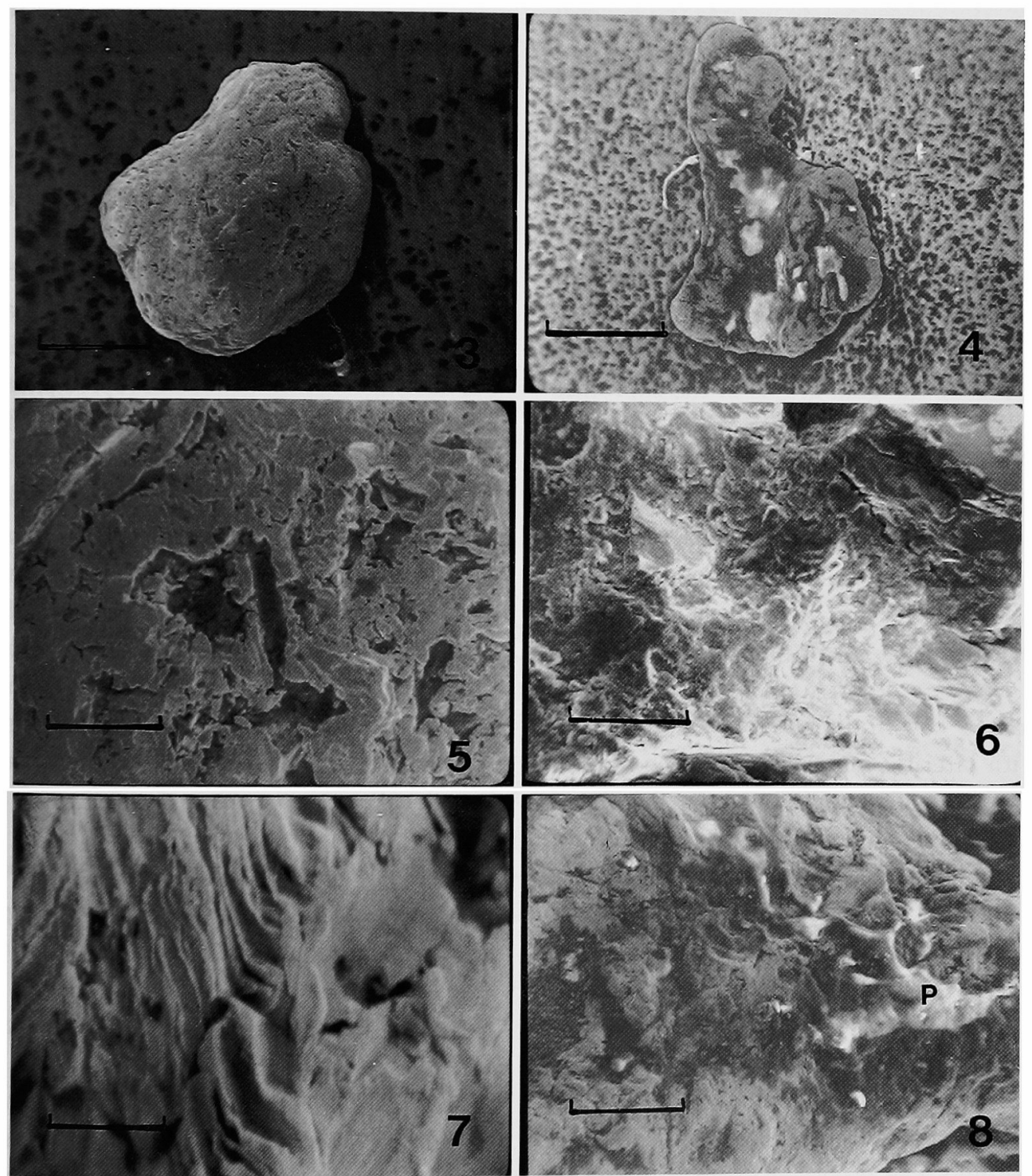

Figs. 3 to 8. Scanning Electron Microphotographs of gold grains separated from various horizons of Nilambur laterites. Details of grain morphology and textural patterns are discussed in the text. "P" indicates painted gold. The bar scales represent 200 microns in Figs. 3 and 4, 20 microns in Fig. 5 and 15 microns in Figs. 6, 7 and 8. 
trates under a binocular microscope. More than hundred grains were separated and examined. Selected grains showing morphological diversity were studied in detail using a Scanning Electron Microscope at the Department of Geosciences, Faculty of Science, Osaka City University.

The morphological parameters documented during the present study include the general shape of the grain, contour pattern, types of faces, the glance of the metal, the degree of etching on the surface and peculiar textural patterns, if any. Our studies indicate that the gold grains from the various zones of weathering in individual profiles have distinctly different shapes. While those occurring towards the upper (highly to completely weathered) horizons usually have near-spherical or ovoidal shapes (Fig. 3), the gold grains in the saprolitic and clayey horizons tend to be more irregular, elongated or polygonal (Fig. 4). Regular grain contours and rounded faces are typical of the first category whereas the second category comprises xenomorphic grains with plane phases and jagged grain contours. The surface of spherical grains usually contains numerous etched pits or corrosion cavities (Fig. 5), in many cases constituting a porous net-work filled with lateritic material, giving an overall dull lustre. On the other hand, in the lower horizons, the irregular grains exhibit bright crystal fases with very low or almost nil degree of etching.

Perhaps, the most interesting observations made during this study are the incipient growth patterns of secondary gold resulting from low temperature reprecipitation. Minute filaments, tufts or dendrites of gold were found to have grown attached to iron-oxides. Such textured gold was observed in many large etched pits of primary (not reprecipitated) grains (Fig. 6). Such 'aboroscent' dendrites have been described from many laterite weathering profiles elsewhere in the world (eg: Freyssinet et al., 1989) and are considered to typify secondary chemical precipitation. Many of the spherical and oval grains contain closelywoven petaloids of secondary gold within deep chemical corrosion cavities (Fig. 7). The most spectacular growth of secondary gold with high purity was exemplified by the bright coatings of "painted gold" over dull primary grains (Fig. 8). The contrast in the glance of the metal, complete absence of etching or corrosion and "spray-painted" appearance of such precipita. tions markedly distinguish them from the dull primary grains over which they are usually developed.

The morphological characteristics and tex. tural associations of gold grains in laterite weathering profiles of Nilambur indicate chemical dissolution, migration and reprecipitation of gold in low temperature supergene environments. Irregular grain surfaces have been chemically dissolved, resulting in the rounded grains and relatively smaller grain size of gold in the upper zones of the weathered profiles. This chemical rounding is distinctly different from that which develops through extensive physical transport like in alluvial sediments. Corrosion and chemical rounding are also supported by the varying intensities of etched pits developed over the grain surface.

\section{Mechanism of Supergene Gold Formation}

Several studies on secondary gold genesis have repeatedly identified the role of oxide, sulfide and chloride complexes, Eh-pH variations and temperature fluctuations in laterite profiles as constraining factors (Boyle, 1979; Mann, 1983, 1984). It is evident that there are a number of complex chemical reactions involved in the processes of dissolution, migra. tion and redeposition of gold in weathered zones. Laboratory chemical experiments have shown that gold is soluble in certain chemical 
solutions which approximate the composition of natural fluids (for instance, Cloke and Kelley, 1964; Lankin et al., 1974). On theoretical grounds, Krauskopf (1951) deduced the importance of $\mathrm{Cl}$-ion, low $\mathrm{pH}$ and high $\mathrm{Eh}$ on the solubility of gold. In a typical weathering profile, the oxidation of pyrite is a controlling factor in gold enrichment. Pyrite and other sulfide minerals are unstable in aqueous environments where they are exposed to oxidants such as dissolved oxygen. When they are sub. jected to weathering, a variety of sulfur and sulfoxy ions are formed, being stable under the pH range between 2 and 9 . Such complexing agents give soluble complexes which render gold mobile in neutral and alkaline $\mathrm{pH}$ range (Boyle, 1979). It was also noted that if these sulfide solutions are left to oxidize in air, they would form sulfates and thiosulfates. These findings strongly support the "dissolution mechanism" of gold under varying redox conditions in the presence of sulfides in aqueous environ- ments, as detailed below.

The oxidation of pyrite in presence of acidic $\mathrm{Fe}^{3+}$ produces $\mathrm{H}_{2} \mathrm{SO}_{4}$ acid, which reacts with $\mathrm{NaCl}$ commonly present in low tempera. ture solutions to form $\mathrm{HCl}$, especially under tropical climatic conditions as prevalent in Nilambur. The latter attacks the $\mathrm{MnO}_{2}$ present in the minerals to give nacent chlorine which dissolves primary gold (Cloke and Kelley, 1964). The lack of detailed information on the mechanism and rates of reactions which govern the partitioning of chemical species between solid and aqueous phases constrains the use of the solute transport model. The possible dissolution mechanisms for gold depo. sition are thus: (1) the mobility of gold as its sulfur and sulfoxy complexes such as $\left[\mathrm{Au}\left(\mathrm{S}_{2} \mathrm{O}_{3}\right)\right]^{-}$, which are stable under alkaline conditions and when they come into contact with high oxygen acid-environment, they are oxidised to sulfates and thiosulfates, reducing the metal to pure gold or (2) the mobility of

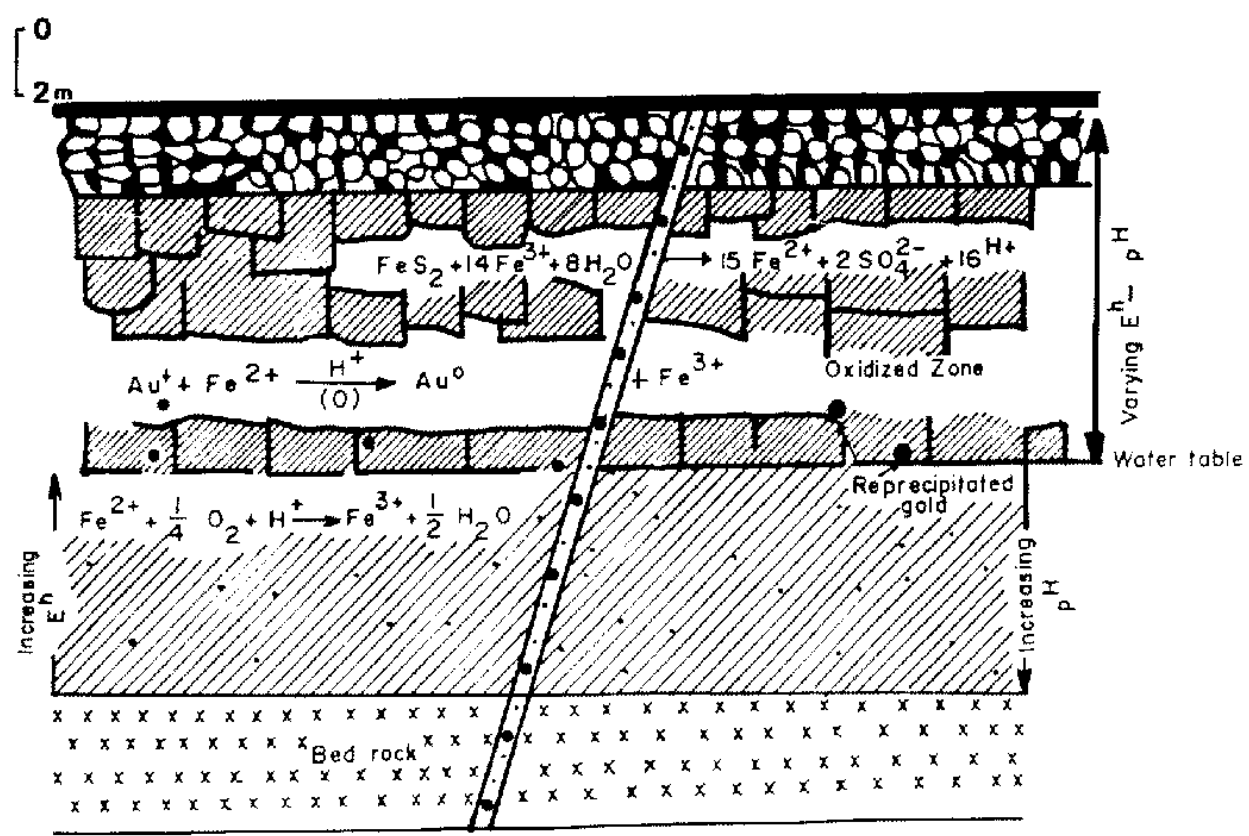

Fig. 9. Schematic diagram showing the model and chemical reactions related to the dissolution, migration and reprecipitation of gold in the laterite weathering profiles of Nilambur. See text for discussion. 
gold as its chlorocomplexes such as $\left[\mathrm{AuCl}_{2}\right]^{-}$ or $\left[\mathrm{AuCl}_{4}\right]^{-}$which are stable under acid conditions and when they migrate downward to a neutral-alkaline setting, the complexes dissociate and gold is precipitated. Both conditions leading to gold precipitation usually prevail in typical natural weathering profiles of laterite formation.

Based on the above theoretical data base and our field and laboratory studies, it is possible to model the dissolution, migration and deposition parameters of supergene gold in the Nilambur area, as schematically shown in Fig. 9. Through the oxidation of acidic $\mathrm{Fe}^{3+}-$ catalysed pyrite, a tendency for the development of an acid profile is triggered and chloride complex of gold will be formed, rendering gold highly mobile. Reaction with gangue minerals and wall rocks, however, leads the complexbearing acid profile to become neutral or somewhat alkaline, which then precipitates gold or dissolves it as sulfur complexes. Mobility of gold in Nilambur thus appears to have been effected in alkaline or neutral medium through sulfur and sulfoxy complexes since the Eh is very low in this environment to oxidise the complexes to sulfate and metallic gold. In the high Eh and acidic environment of the oxidised zone (laterite), the neutral or alkaline complexes got reduced with the resultant precipitation of the pure metal.

In the natural environment of tropical weathering at Nilambur and laterite formation, rain water percolates through organic debris and top soil to produce a slightly acid solution, which attacks the disseminated sulfide minerals present in the mineralised rock. This triggers "ferrolysis" reaction whereby ferrous iron is oxidised to ferric iron, creating a highly acidic condition which is conducive to the release and mobility of gold as chloride complexes. We infer that ferrolysis reaction could have been fundamental to the supergene gold genesis in
Nilambur. The occurrence of gold particles within iron oxides and agglutination or coating on iron oxides as found in Nilambur are taken as evidences for this. When ferrolysis reactions are retarded due to prolonged weathering of pyrite, the $\mathrm{Fe}^{2+}$ ions act as effective reducing agents, leading to the reduction of acid com. plexes of gold to its metallic state. This essentially appears to be the process which led to the concentration of refined gold nuggets with increased grain size and fineness in the supergene gold occurrences as in the Nilambur laterites.

Acknowledgements: The Iaboratory studies presented in this paper were carried out by the senior author during the course of a Fellowship visit to the Osaka City University supported by the Japan Society for the Promotion of Science. The support received from the Society is gratefully acknowledged. The authors thank Dr. Akira Yao of the Dept. of Geosciences, Osaka City University for all his kind interest and help in SEM studies of gold grains. MS and PKO acknowledge the Director of Centre for Earth Science Studies for all logisitic support. The authors wish to place on record their gratitude to the two anonymous Referees of this Journal whose helpful com. ments have greatly aided in improving the manuscript.

\section{References}

Boyle, R.W. (1979), The geochemistry of gold and its deposits. Geol. Surv. Canada Bull, 280, $431-445$.

Cloke, P.L. and Kelley. W.C. (1964), Solubility of gold under inorganic supergene conditions. Econ. Geol., 59, 259-270.

Freyssinet, Ph., Zeegers, H. and Tardy, Y. (1989), Morphology and geochemistry of gold grains in lateritic profiles of southem Mali. J. Geochem. Expl., 32, 17-31.

Krauskopf, K.B. (1951), The solubility of gold. Econ. Geol., 46, 858-870.

Lankin, H.W., Curtin, G.C., Hubert, A.E., Shack- 
lette, H.T. and Doxtader, G. (1974), Geochemistry of gold in the weathering cycle. U.S. Geol. Surv. Bull., 1330, 80p.

Mann, A.W. (1983), Hydrogeochemistry and weathering on the Yilgarn Block, Western Australia-Ferrolysis and heavy metals in continental brines. Geochim. Cosmochim. Acta, 47, $181-190$.

Mann, A.W. (1984), Mobility of gold and silker in lateritic profiles: some observations from western Australia. Econ. Geol. 79, 38-49.

Nair, N.G.K., Santosh, M. and Mahadevan, R. (1987), Lateritisation as a possible contributor to gold placers in Nilambur valley, south-west India. Chem. Geot., 60, 309-315.
Santosh, M. (1989), Mineral resources of Kerala : a case study of Nilambur gold deposit as lineament-related mineralization. Kerala Sci. Congress, Cochin (Abstr.).

Sawarkar, A.R. (1980), Geological and geomorphological features of Nilambur valley, Kozhikode district, Kerala, with special reference to the alluvial gold deposits of the area. Geol. Surv. India Publ, 5, 29-38.

Wilson, A.F. (1984), Origin of guartz free gold nuggets and supergene gold found in the later ites and soils: a review of some new observa. tions. Austr. J. Earth Sci., 31, 303-316.

\section{南インド, ニランブールのラテライト中の金鉱床一浅部風化鉱床の生成モテル}

$$
\text { M. サントシ・P.K.オーマナ・䓀田 勝 }
$$

ラテライト中に金の数粉，砂粒あるいはナゲットが産出する例が最近各地で報告され，その成因諭の構 案が注目を浴びつつある。南インド、ニランブール鉱床では，金の特徽的な㦃状之組織が観察をれ、それ

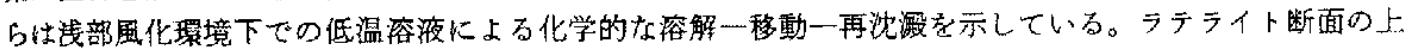

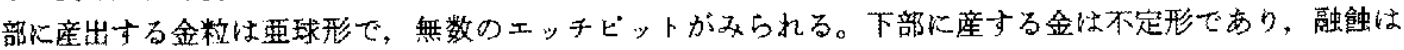

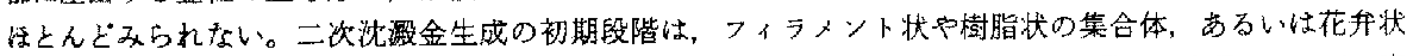

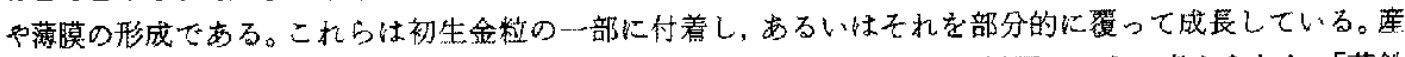

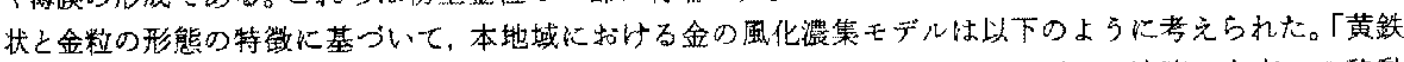

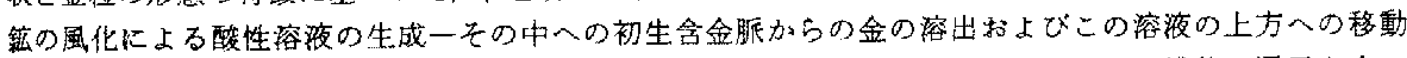

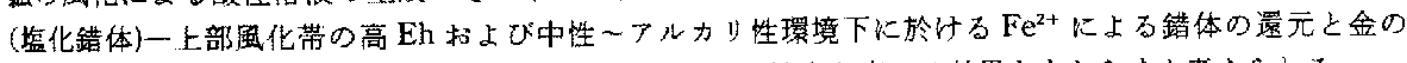
虬酒」。化学的再沈激は浅部風化環境下゙で生成される金の純度る高める效果をむたらすと考えられる。 